\title{
Peranan Aplikasi Sistem BOP PAUD yang Akuntabel untuk Guru PAUD Kota Semarang
}

\section{The Role of BOP PAUD System Aplication Accountable for PAUD Teachers in Semarang City}

\author{
Zaky Machmuddah ${ }^{1}$, Entot Suhartono ${ }^{2}$ \\ ${ }^{1,2}$ Fakultas Ekonomi dan Bisnis Universitas Dian Nuswantoro, J1. Nakula I No. 5-11 Semarang, 50131 \\ Telp. (024) 3567010, Faks. (024) 3567010 \\ e-mail: ${ }^{1}$ zaky.machmuddah@dsn.dinus.ac.id, ${ }^{2}$ entot.suhartono@dsn.dinus.ac.id
}

\begin{abstract}
Abstrak
Organisasi HIMPAUDI (himpunan pendidik dan tenaga kependidikan anak usia dini) beranggotakan guru PAUD berjumlah 1051 guru. Bergerak dibidang non profit oriented organization, berperan membantu pemerintah melayani pendidikan anak serta mencerdaskan kehidupan bangsa. Permasalahan yang dimiliki oleh anggota HIMPAUDI adalah minimnya kompetensi dalam penguasaan teknologi laporan pertanggungjawaban bantuan operasional penyelenggaraan PAUD (BOP PAUD) dan belum tersedianya aplikasi sistem yang membantu pembuatan laporan pertanggungjawaban BOP PAUD yang akuntabel dan transparan. Hal tersebut dibuktikan dengan data yang tersedia menyatakan bahwa 32,7\% guru PAUD anggota HIMPAUDI berpendidikan terakhir SMA dan 95\% guru PAUD anggota HIMPAUDI Kota Semarang berlatar belakang pendidikan di luar bidang akuntansi dan keuangan. Sehingga diperlukan peningkatan kompetensi dasar dalam hal laporan pertanggungjawaban BOP PAUD bagi guru PAUD anggota HIMPAUDI Kota Semarang yang dibantu dengan tersedianya aplikasi sistem pertanggungjawaban BOP PAUD untuk mempermudah pembuatan laporan pertanggungjawaban BOP $P A U D$ yang akuntabel dan transparan. Luaran yang dihasilkan adalah meningkatnya kompetensi dan pengetahuan dalam penyusunan laporan pertanggungjawaban BOP PAUD sebesar 5\% dari keseluruhan guru PAUD anggota HIMPAUDI Kota Semarang dan penggunaan aplikasi sistem pertanggungjawaban BOP PAUD meningkat 5\% sehingga laporan pertanggungjawaban BOP PAUD yang dananya dikucurkan oleh Pemerintah dapat disajikan sesuai dengan prinsip penggunaan DAK Non Fisik BOP PAUD yang akuntabel dan transparan.
\end{abstract}

Kata kunci: aplikasi sistem, akuntabel, transparan, BOP PAUD.

\begin{abstract}
The HIMPAUDI organization (association of early childhood educators and education staff) consists of 1051 ECD teachers. Moves in a non-profit oriented organization, whose role is to help the government serve children's education and educate the life of the nation. The problems that HIMPAUDI members have are the lack of competency in mastering the technology of operational assistance accountability reports for PAUD implementation (BOP PAUD) and the unavailability of system applications that help create accountable and transparent BOP PAUD accountability reports. This is evidenced by the available data stating that 32.7\% of HIMPAUDI members of PAUD teachers were educated in senior high school and 95\% of HIMPAUDI PAD members in Semarang City had educational backgrounds outside of accounting and finance. So that it is necessary to increase basic competencies in terms of BOP PAUD accountability reports for PAUD teachers in Semarang City HIMPAUDI members who are assisted by the availability of BOP PAUD accountability systems to facilitate the accountability and transparent accountability of BOP PAUD reports. BOP PAUD
\end{abstract}


accountability report of 5\% of all PAUD teachers in Semarang City HIMPAUDI member and application of BOP PAUD accountability system increased by 5\% so that the BOP PAUD accountability report whose funds were disbursed by the Government can be presented in accordance with the principle of accountable and non-BOP PAUD DAK transparent.

Kata kunci: system applications, accountable, transparent, BOP PAUD.

\section{PENDAHULUAN}

Perkembangan anak usia dini merupakan tahap yang paling penting dalam masa hidup manusia. Maju dan berkembangnya pembangunan suatu bangsa dan negara sangat ditentukan oleh keseriusan pemerintah dalam mempersiapkan generasi penerusnya. Begitu pula dengan lembaga PAUD, maju dan berkembangnya PAUD yang berkualitas tidak hanya menjadi tanggunjawab Pemerintah pusat, tetapi harus bersinergi antara peran pemerintah daerah, swasta, lembaga PAUD, masyarakat dan keluarga. Untuk meningkatkan layanan PAUD yang inklusif, adil dan bermutu serta berkelanjutan sejak tahun 2016 Pemerintah Pusat dalam hal ini Kementerian Pendidikan dan Kebudayaan berperan membantu lembaga PAUD melalui BOP PAUD. Dengan demikian lembaga PAUD harus dapat merencanakan, mengelola, mempertanggungjawabkan, dan melaporkan secara akuntabel dan transparan BOP PAUD.

Untuk dapat mewujudkan perencanaan, pengelolaan, pertanggungjawaban, dan pelaporan secara akuntabel dan transparan BOP PAUD maka pengelola PAUD harus memiliki kompetensi dibidang tersebut. Berdasarkan data HIMPAUDI Kota Semarang tahun 2017 dari 1051 anggota HIMPAUDI sebanyak 32,7\% berpendidikan terakhir SMA dan 5\% dari anggota HIMPAUDI memiliki ketrampilan tata buku (akuntansi), 54,9\% perpendidikan terakhir D4/S1, S2 namun tidak memiliki kompetensi di bidang akuntansi. Oleh karena itu, hal ini merupakan masalah dasar yang dialami oleh HIMPAUDI. Selain hal tersebut, sebagai lembaga yang kebanyakan masih baru, pengelolaan keuangan seringkali masih dikelola apa adanya, manual dan kurang terencana. Hal ini tentu mempengaruhi imunitas lembaga untuk memberikan pelayanan pendidikan yang baik, sehingga diperlukan peningkatan kompetensi dasar dalam hal pengelolaan keuangan bagi guru-guru PAUD yang dibantu dengan tersedianya aplikasi sistem pertanggungjawaban BOP PAUD berbasis web untuk mempermudah pelaporan BOP PAUD yang akuntabel dan transparan.

Teknologi informasi berpotensi untuk membantu menyelesaikan pekerjaan dengan lebih cepat, lebih fleksibel dan lebih efisien [1]. Begitu pula dengan [2] menjelaskan bahwa aplikasi MS Office sangat berhubungan erat dengan para pendidik untuk membantu tugas kependidikan sehari-hari. Sejalan dengan pernyataan tersebut [3] menyatakan bahwa aplikasi tersebut membantu dalam pembelajaran, mengevaluasi dan pembuatan laporan akhir pembelajaran. Apabila digunakan secara optimal sesuai dengan menu-menu yang disediakan penggunaan aplikasi ini akan menunjang pekerjaan para pendidik [4]. Namun demikian kurang menguasainya penggunaan komputer untuk menunjang pekerjaan seharihari dialami oleh pendidik PAUD di Kota Semarang yang berpendidikan SMA dan Sarjana S1 [5].

Berdasarkan latar belakang sesuai dengan fenomena yang terjadi maka diperlukan program kemitraan masyarakat untuk menyelesaikan masalah tersebut, yaitu dengan memberikan pelatihan dan penyediaan aplikasi sistem pertanggungjawaban BOP PAUD untuk membantu meringankan pekerjaan para pendidik secara akuntabel dan transparan.

\section{METODE PELAKSANAAN}

Permasalahan mendasar yang ada di HIMPAUDI Kota Semarang adalah sebagai berikut:

1. minimnya kompetensi dalam penguasaan teknologi mengenai laporan pertanggungjawaban BOP PAUD,

2. belum tersedianya aplikasi sistem yang membantu pembuatan laporan pertanggungjawaban BOP PAUD yang akuntabel dan transparan. 
Oleh karena itu, perlu dilakukannya program kemitraan masyarakat untuk menyelesaikan permasalahan yang ada di HIMPAUDI Kota Semarang. Berdasarkan kesepakatan dengan Ibu Rr. Evi Trisnowati, SPd selaku ketua HIMPAUDI Kota Semarang, melalui program kemitraan masyarakat ini akan membantu guru-guru PAUD anggota HIMPAUDI Kota Semarang dengan menyediakan aplikasi sistem pertanggungjawaban BOP PAUD yang akuntabel dan transparan untuk meringankan pekerjaan para guru-guru PAUD.

Berdasarkan analisis masalah tersebut maka solusi yang ditawarkan dalam program kemitraan masyarakat ini adalah peningkatan kompetensi dasar dalam hal pembuatan laporan pertanggungjawaban BOP PAUD bagi guru/penyelenggara PAUD dan penyediaan aplikasi sistem laporan pertanggungjawaban BOP PAUD yang akuntabel dan transparan. Dengan demikian, target luaran dari program kemitraan ini adalah kompetensi dan pengetahuan di bidang penyusunan laporan pertanggungjawaban BOP PAUD guru-guru PAUD anggota HIMPAUDI Kota Semarang meningkat 5\% serta peningkatan pengoperasian aplikasi sistem pertanggungjawaban BOP PAUD sebesar 5\% dari seluruh anggota HIMPAUDI Kota Semarang sehingga laporan pertanggungjawaban BOP PAUD dapat disajikan secara akuntabel dan transparan.

Solusi yang pertama yaitu peningkatan kompetensi dasar dalam hal penyusunan laporan pertanggungjawaban BOP PAUD bagi guru-guru PAUD diberikan karena berdasarkan data yang diperoleh menyatakan bahwa 95\% guru-guru PAUD anggota HIMPAUDI belum memiliki kompetensi dibidang penyusunan laporan pertanggungjawaban BOP PAUD. Sehingga tujuan dari solusi yang pertama adalah untuk memberikan pengetahuan mengenai pentingnya akuntabilitas dalam menyajikan laporan pertanggungjawaban BOP PAUD.

Sedangkan solusi kedua yang diberikan adalah penyediaan aplikasi sistem pertanggungjawaban BOP PAUD dengan alasan karena untuk mempermudah proses pelaporan sehingga laporan pertanggungjawaban BOP PAUD secara akuntabel dan transparan dapat terwujud. Pada akhirnya aplikasi sistem pertanggungjawaban BOP PAUD berbasis web ini akan dimanfaatkan untuk seluruh guru-guru PAUD anggota HIMPAUDI di Indonesia.

\section{HASIL DAN PEMBAHASAN}

Tahap pertama dari program kemitraan masyarakat ini adalah melaksanakan sosialisasi kepada guru PAUD anggota HIMPAUDI kota Semarang. Kegiatan sosialisasi telah dilaksanakan dan berjalan dengan baik, terbukti peserta sosialisasi telah memperoleh materi sosialisasi dan memperoleh tambahan pengetahuan mengenai aplikasi sistem BOP PAUD. Berikut ini adalah gambaran kegiatan sosialisasi yang telah dilaksanakan:
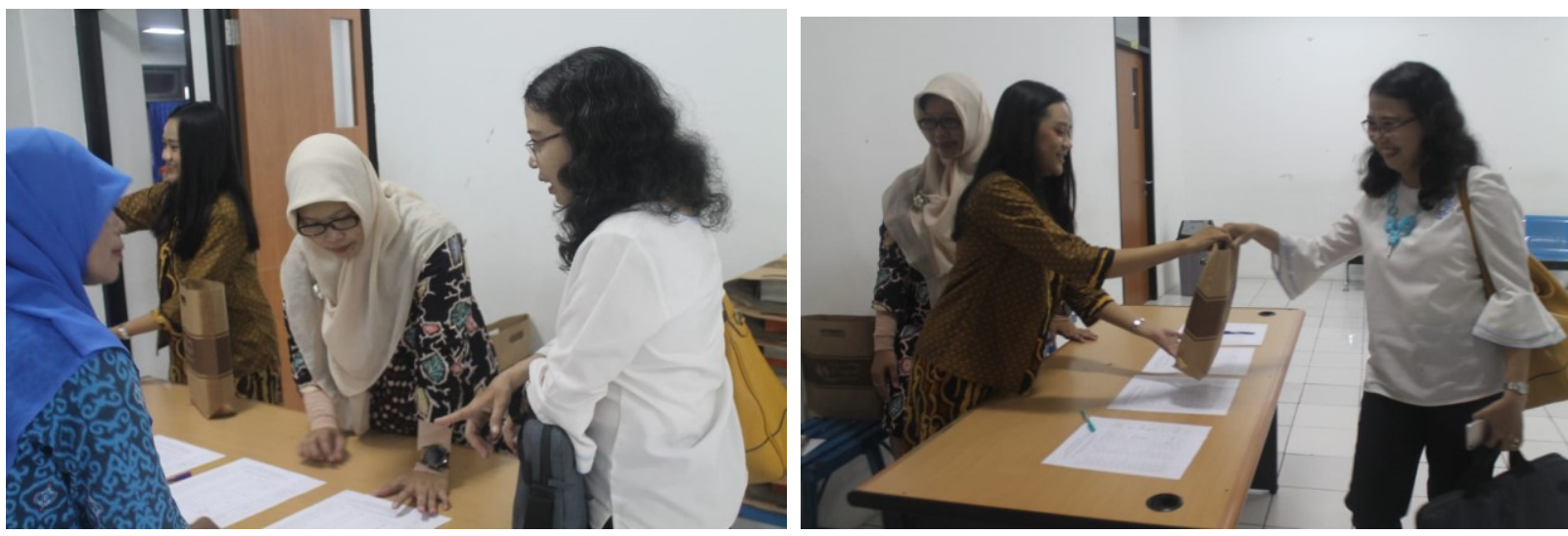

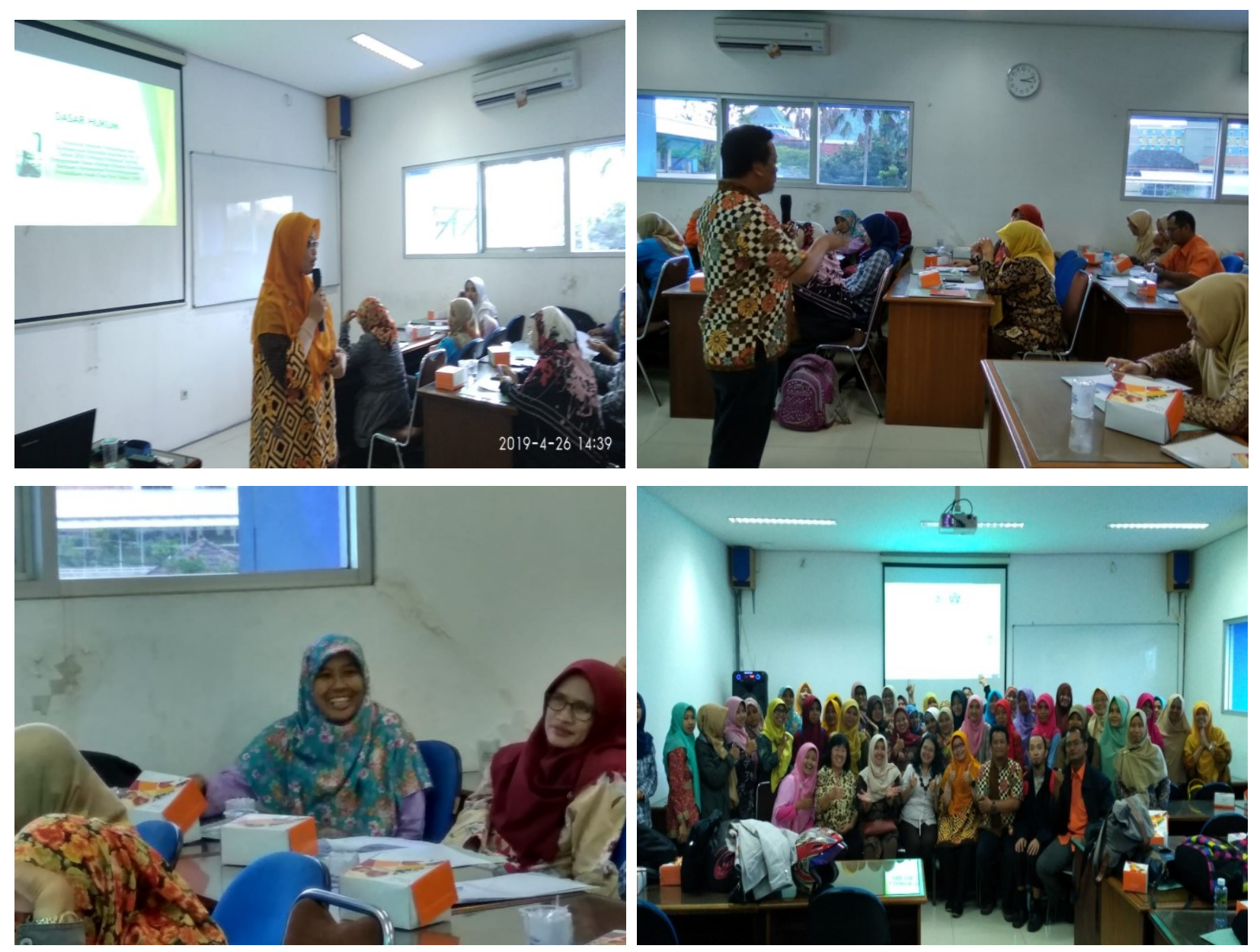

Gambar 1. Kegiatan Sosialisasi Program Kemitraan Masyarakat

Tahap uji coba merupakan langkah kedua dari solusi yang diberikan. Dalam tahapan ini peserta program kemitraan masyarakat mendapatkan pengetahuan berupa gambaran aplikasi sistem BOP PAUD. Respon baik dari peserta program kemitraan masyarakat dengan adanya kegiatan uji coba aplikasi sistem didapatkan, terbukti dengan adanya saran dari para peserta program kemitraan masyarakat terkait dengan aplikasi sistem BOP PAUD yang diuji cobakan, sehingga dapat digunakan untuk memperbaiki aplikasi sistem BOP PAUD agar lebih sempurna. Tahap uji coba dapat digambarkan pada gambar di bawah ini
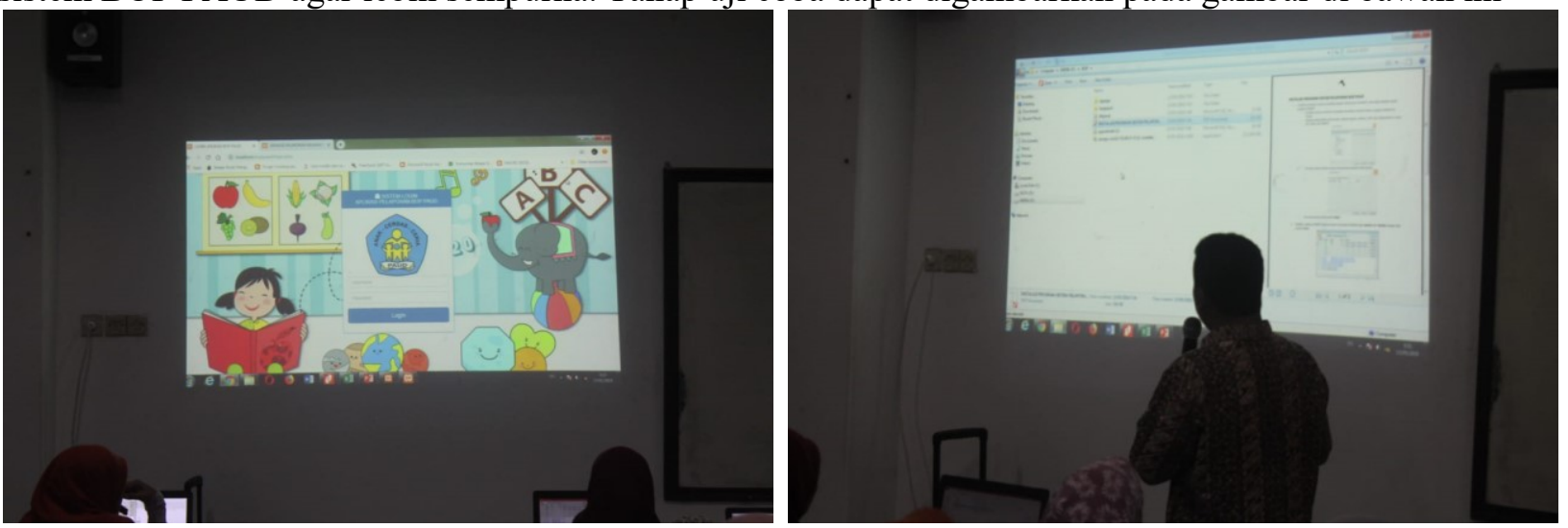

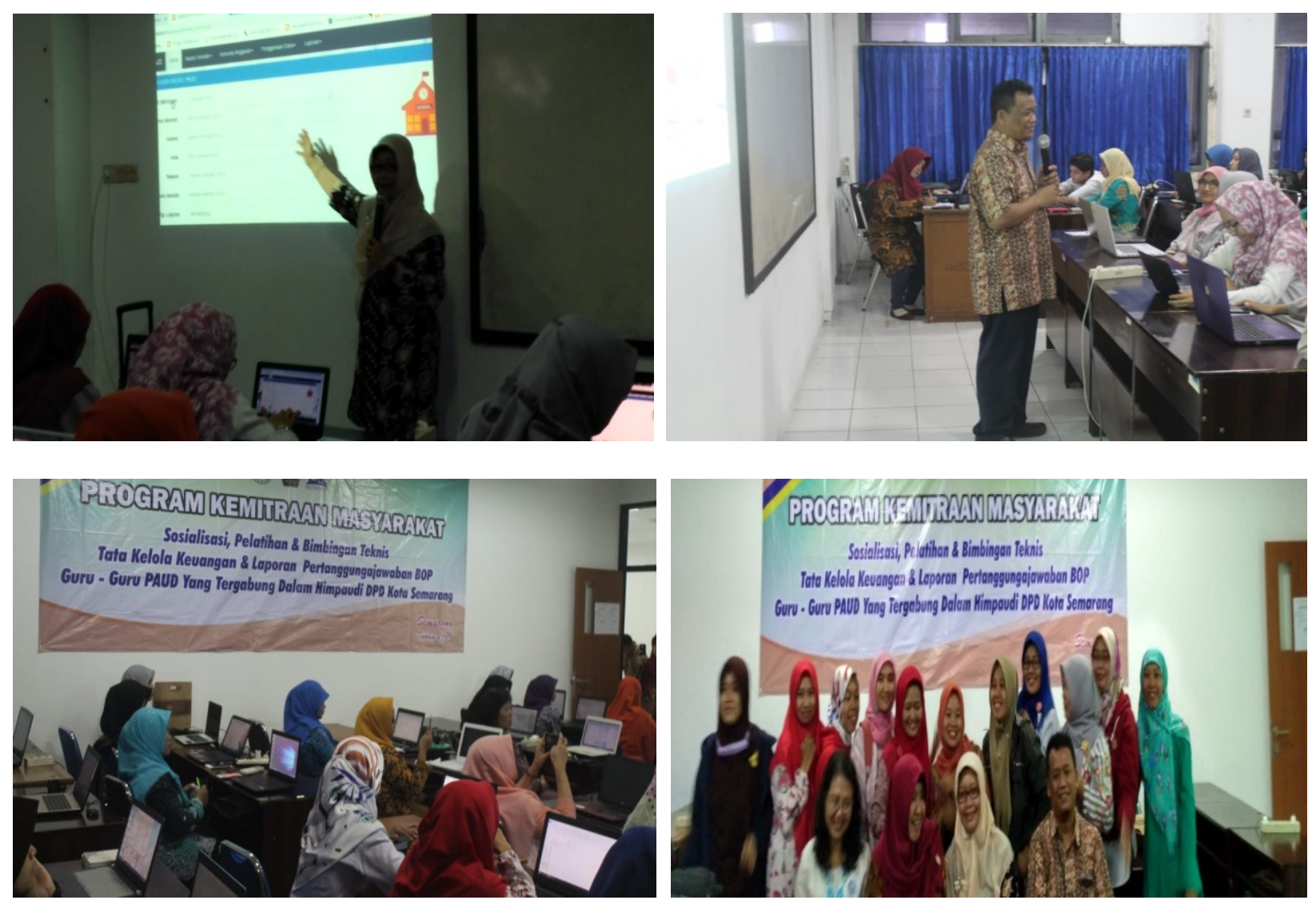

\section{Gambar 2. Tahap Uji Coba Sistem BOP PAUD}

Terakhir adalah tahap bimbingan teknis. Aplikasi sistem BOP PAUD telah disempurnakan sesuai dengan saran dari peserta program kemitraan masyarakat. Hasil yang diperoleh dari kegiatan tahap terakhir ini adalah peserta program kemitraan masyarakat memahami dan menggunakan aplikasi sistem BOP PAUD di instansinya, serta peserta program kemitraan masyarakat memperoleh sertifikat bimbingan teknis aplikasi sistem BOP PAUD. Bukti pelaksanaan kegiatan bimbingan teknik dapat dilihat pada gambar 3.
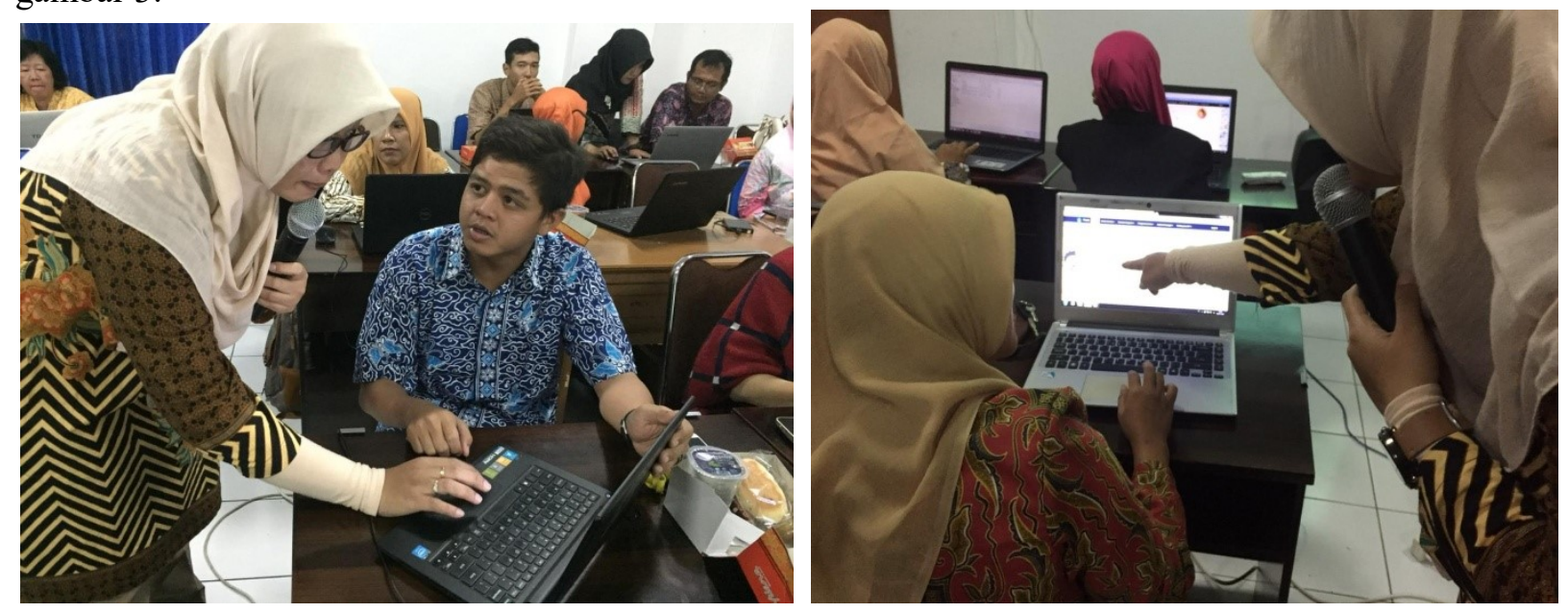

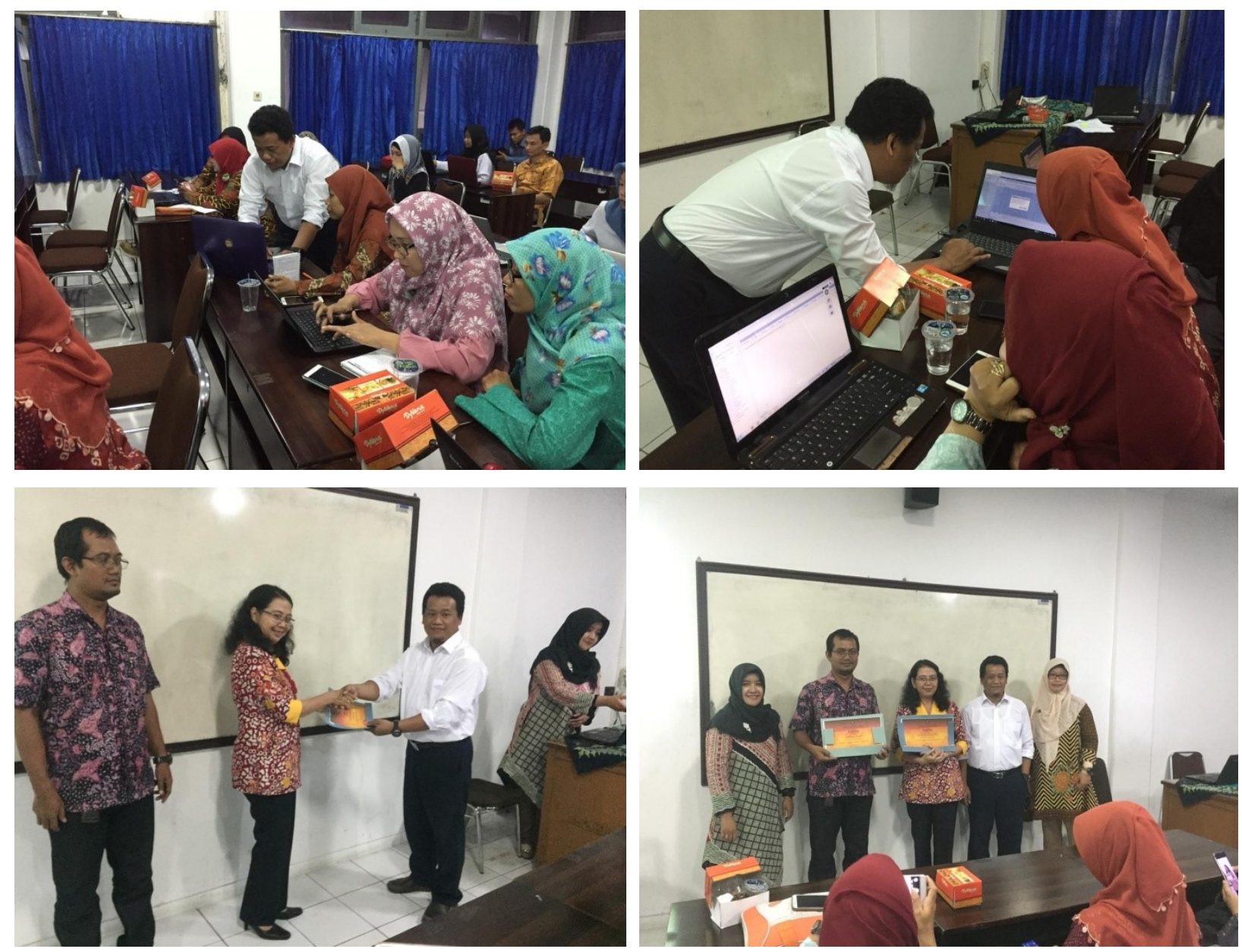

Gambar 3. Kegiatan Bimbingan Teknis

Berikut ini adalah kesimpulan dari target output dan capaian program kemitraan masyarakat:

\begin{tabular}{|c|c|c|c|}
\hline No. & Tahap & Output & Capaian \\
\hline 1. & $\begin{array}{l}\text { Tahap Persiapan dan Sosialisasi: } \\
\text { Menyiapkan materi sosialisasi dan } \\
\text { aplikasi sistem BOP PAUD. }\end{array}$ & $\begin{array}{l}\text { Materi Sosialisasi dan tambahan } \\
\text { pengetahuan mengenai aplikasi } \\
\text { sistem BOP PAUD. }\end{array}$ & $100 \%$ \\
\hline 2. & $\begin{array}{l}\text { Tahap Uji Coba: } \\
\text { Menyiapkan aplikasi sistem BOP } \\
\text { PAUD dan soal latihan. }\end{array}$ & $\begin{array}{l}\text { Peserta mendapatkan pengetahuan } \\
\text { berupa gambaran aplikasi sistem } \\
\text { BOP PAUD. }\end{array}$ & $100 \%$ \\
\hline 3. & $\begin{array}{l}\text { Tahap Bimbingan Teknis: } \\
\text { Menyiapkan aplikasi sistem BOP } \\
\text { PAUD yang sempurna dan bimbingan } \\
\text { teknis untuk anggota HIMPAUDI kota } \\
\text { Semarang }\end{array}$ & $\begin{array}{l}\text { Peserta memahami aplikasi sistem } \\
\text { BOP PAUD dan mendapatakan } \\
\text { bimbingan teknis dan sertifikat } \\
\text { pelatihan aplikasi } \\
\text { PAUD. }\end{array}$ & $100 \%$ \\
\hline
\end{tabular}

\section{KESIMPULAN}

Program kemitraan masyarakat ini bermanfaat bagi anggota HIMPAUDI kota Semarang, dengan luaran berupa aplikasi sistem laporan pertanggungjawaban BOP PAUD yang dananya dikucurkan oleh Pemerintah dapat disajikan sesuai dengan prinsip penggunaan DAK Non Fisik BOP PAUD yang akuntabel dan transparan. 


\section{SARAN}

Setelah kegiatan program kemitraan masyarakat dilaksanakan dari tahap persiapan sampai dengan tahap evaluasi, maka saran yang diberikan untuk kegiatan berikutnya adalah:

1. Sebaiknya pelaksanaan bimbingan teknis aplikasi sistem BOP PAUD dilaksanakan di ruang labolatorium.

2. Sebaiknya jadwal bimbingan teknis aplikasi sistem BOP PAUD dilaksanakan secara berkelanjutan.

\section{UCAPAN TERIMA KASIH}

Tim program kemitraan masyarakat mengucapkan terimakasih kepada Lembaga Penelitian dan Pengabdian Masyarakat (LPPM) Universitas Dian Nuswantoro atas izin yang diberikan serta dukungan pendanaan. Selain itu, tim program kemitraan masyarakat juga mengucapkan terimakasih kepada Ketua HIMPAUDI kota Semarang atas kerjasamanya serta guru PAUD anggota HIMPAUDI kota Semarang yang bersedia meluangkan waktunya untuk menjadi peserta bimbingan teknis BOP PAUD.

\section{DAFTAR PUSTAKA}

[1] Roca, et. al. 2006. Understanding e-learning Continuance Intention: A extension on the thechnology Acceptence Model. International Journal Human Computer Studies. 64. Pp. 683-696.

[2] Rusman. 2012. Belajar dan Pembelajaran Berbasis Komputer. Bandung: Alfa Beta.

[3] Kurniawan, A. 2007. Ms Office Power Point 2007, Bandung: PT. Pradya Paramitha.

[4] Tosin, Rijanto, dan Ramon, Valentzia. 2000. Microsoft Office 2000. Jakarta: Dinastindo.

[5] Ratnawati Juli, Imam N, Eko H, Kusni I. 2018. IBM Himpunan Pendidikan Anak Usia Dini Kota Semarang. Abdimasku. 2018. Vol. 1 No. 2, Juli, Hal. 80-83. 